\title{
Sputtering of cryogenic films of hydrogen by keV ions Thickness dependence and surface morphology
}

Schou, Jørgen; Hilleret, N.

Publication date:

2008

Link back to DTU Orbit

\section{Citation (APA):}

Schou, J., \& Hilleret, N. (2008). Sputtering of cryogenic films of hydrogen by keV ions: Thickness dependence and surface morphology. Abstract from 23rd International Conference on Atomic Collisions in Solids, Phalaborwa, South Africa.

\section{General rights}

Copyright and moral rights for the publications made accessible in the public portal are retained by the authors and/or other copyright owners and it is a condition of accessing publications that users recognise and abide by the legal requirements associated with these rights.

- Users may download and print one copy of any publication from the public portal for the purpose of private study or research.

- You may not further distribute the material or use it for any profit-making activity or commercial gain

- You may freely distribute the URL identifying the publication in the public portal

If you believe that this document breaches copyright please contact us providing details, and we will remove access to the work immediately and investigate your claim. 


\section{Sputtering of cryogenic films of hydrogen by keV ions: Thickness dependence and surface morphology.}

\section{Jorgen Schoup and Noel Hilleret ${ }^{2}$}

The solid hydrogen isotopes are the most volatile solids which exist in equilibrium with vacuum. For bombardment with $10 \mathrm{keV}$ hydrogen ions the sputtering yield of these solids ranges from $200 \mathrm{D}_{2}$ /ion for the less volatile solid deuterium up to $1000 \mathrm{H}_{2} /$ ion for the most volatile solid, solid hydrogen [1]. The sputtering of thick films takes places via non-radiative electronic transitions which eventually liberate energy for ejection of the sputtered molecules.

Sputtering data for solid hydrogen have been obtained at the experimental setup at CERN $[2,3]$ and sputtering data for solid hydrogen and deuterium at the setup Risø [2]. In both setups the films were deposited on a metal substrate kept at a temperature of 2-3 K, and the thickness ranged from a fraction of a monolayer up to several thousands monolayers. For ultrathin films the interaction between the underlying metallic substrate and the ion is important, but it is not clear how this process works.

The sputtering yield of the film depends strongly on the thickness. The sputtering yield decreases with two orders of magnitude from a maximum of about one monolayer $\left(\sim 10^{15} \mathrm{H}_{2} / \mathrm{cm}^{2}\right)$ with increasing film thickness $d$. Even for very thick films - 10 times thicker than the ion range - the yield continues to decrease as $d^{-3 / 2}$ for films preparedint thermodynamic equilibrium. This surprising dependence on average thickness even for films much thicker than the ion range can only be explained by a thickness dependent surface morphology, e.g. the film molecules aggregate as clusters on top of a uniform film of a few monolayers. Under these circumstances some ions can still reach the substrate even for an average film thickness larger than the range and influence the sputtering yield. Only isotopic combinations of the hydrogens exhibit such a behavior with a large surface mobility required to form clusters at these low temperatures. The dependence of the sputtering yield will be discussed in terms of the surface morphology.

[1] B. Stenum, J. Schou et al. Phys. Rev. Lett. 67, 2842 (1991)

[2] J. Schou, H. Tratnik, B. Thestrup and N. Hilleret, Surf. Sci. (in press) (2008)

[3] H. Tratnik, N. Hilleret and H. Störi, Vacuum 81, 731 (2007)

1 )Department of Photonics Engineering, Risø Campus, Technical University of Denmark, DK-4000 Roskilde, Denmark. (e-mail: j.schou@risoe.dk)

2) AT-VAC, CERN 1211, CH - Geneva 23, Switzerland 